\title{
Bioactive compounds and value-added applications of cupuassu (Theobroma grandiflorum Schum.) agroindustrial by-product
}

\author{
Russany Silva da COSTA ${ }^{1}$, Orquídea Vasconcelos dos SANTOS ${ }^{2}$ (D), Suzana Caetano da Silva LANNES ${ }^{3}$, \\ Alessandro Alberto CASAZZA ${ }^{4}$, Bahar ALIAKBARIAN ${ }^{4}$, Patrizia PEREGO ${ }^{4}$, Roseane Maria RIBEIRO-COSTA ${ }^{5}$, \\ Attilio CONVERTI ${ }^{4}$, José Otávio Carréra SILVA JÚNIOR ${ }^{1 *}$
}

\begin{abstract}
Cupuassu is a fruitful species from the Amazon basin with great economical potential, due to the multiple uses of its pulp and seeds in the food and cosmetic industries. This fruit generates large amounts of solid waste, which, despite of its high content of bioactive compounds, is discarded in the environment. Therefore, with the aim of reusing these wastes and adding economic value, we investigated the nutritional potential of the seed by-product resulting from industrial cupuassu oil extraction. The by-product was submitted to green extraction, and its contents of bioactive compounds were quantified by HPLC. The extract had a total polyphenol content $\left(16.9 \pm 1.8 \mathrm{mg} / \mathrm{g}_{\mathrm{DM}}\right)$ and an antioxidant activity, ABTS + $(151.0 \pm 5.5 \mathrm{mg} / 100 \mathrm{~g})$ and DPPH $(85.4 \pm 1.7 \mathrm{mmol} / \mathrm{L})$. HPLC analysis of the extract identified epicatechin and glycosylated quercetin as the major flavonoids. This by-product shows great potential for being used as a source of the ingredients of high nutritional value, especially dietary fiber and polyphenols.
\end{abstract}

Keywords: cupuassu; by-product; antioxidant activity; flavonoids; reuse; value-added applications.

Practical Application: The by-product feature potential for its reutilization in different biotechnological processes.

\section{Introduction}

The growing demand for biologically active and low-cost natural substances has stimulated the search for suitable exploitation of fruit processing by-products such as peel and seeds, which are considered cheaper sources of nutrients. Some studies did in fact report nutrient concentrations in fruit wastes even higher than in pulp (Ignat et al., 2011; Pugliese et al., 2013). By-products from processing of tropical fruits have been increasingly used in recent years as food additives and sources of bioactive compounds such as polyphenols (Ayala-Zavala et al., 2011; Pantaleón-Velasco et al., 2014). In addition, the recycling of these residues may reduce the environmental impact associated to their disposal, hence adding value to the whole production chain. Thus, the physicochemical characterization of these by-products and quantification of their bioactive compounds are of great concern to add value and enhance their commercial and industrial reuse, while preserving the biome (Ballesteros et al. 2014; Janissen \& Huynh, 2018)

Cupuassu (Theobroma grandiflorum Willd. ex Spreng.) Schum. is a fruitful species from the Amazon basin with great economical potential, due to the multiple uses of its fruit's pulp and seeds in the food and cosmetic industries, with high economic potential. The oil extracted from its seeds is gaining great interest because of new cosmetic applications, whereas its fruit is widely used in local cuisine due to its pleasant flavor (Carvalho et al., 2004). This exotic fruit, which is rich in polyphenolic compounds, has also been commercialized in the Brazilian and international markets because of its nutritional properties (Pugliese et al., 2013). It has been suggested that its daily consumption may contribute to prevent various diseases (Pantaleón-Velasco et al., 2014).

Based on this background, the aim of this work was to characterize the industrial by-product resulting from cupuassu oil extraction in terms of polyphenols content and antioxidant activity, nutritional composition, physicochemical properties and thermal behavior, so as to check its industrial potential in food applications, hence adding value to the production chain and saving costs.

\section{Material and methods}

\subsection{Chemicals and reagents}

To quantify phenolic compounds by colorimetric and chromatographic methods, the following standards were used: gallic acid (Fluka Chemika, Buchs, Switzerland), D(+)-anhydrous glucose (Carlo Erba, Milan Italy), D(-)-fructose (Merck, Darmstadt, Germany), sucrose (Boehringer, Mannheim, Germany), quercetin dihydrate, glycosylated quercetin, catechin hydrate, p-coumaric acid, (-)-epigallocatechin gallate, (-)-epicatechin,

${ }^{1}$ Laboratório de PङD Farmacêutico e Cosmético, Faculdade de Ciências Farmacêuticas, Universidade Federal do Pará - UFPA, Belém, PA, Brasil

${ }^{2}$ Laboratório de Ciência dos Alimentos, Faculdade de Nutrição, Universidade Federal do Pará - UFPA, Belém, PA, Brasil

${ }^{3}$ Laboratório de Tecnologia de Alimentos, Faculdade de Ciências Farmacêuticas, Universidade de São Paulo - USP, São Paulo, SP, Brasil

${ }^{4}$ Dipartimento di Ingegneria Civile, Chimica e Ambientale, Università di Genova, Genova, Italia

${ }^{5}$ Laboratório de Nanotecnologia Farmacêutica, Faculdade de Ciências Farmacêuticas, Universidade Federal do Pará - UFPA, Belém, PA, Brasil

*Corresponding author: carrera@ufpa.br 
3,4-dihydroxybenzoic, 2,2' -azino-bis(3-ethylbenzothiazoline-6sulfonic acid) diammonium salt, $( \pm)$-6 hydroxy-2,5,7,8-tetramethylchromane-2-carboxylic acid, 2,2-diphenyl-1-picrylhydrazyl (Sigma-Aldrich, Saint Louis, MO, USA). Folin-Ciocalteu phenol reagent was purchased from Sigma-Aldrich.

\subsection{Preparation of the cupuassu seed by-product}

Cupuassu seeds were undergone a baking process at $65^{\circ} \mathrm{C}$ for $45 \mathrm{~min}$, after which they were pressed to remove the oil to be industrially exploited. The resulting by-product, designated as cupuassu seed by-product (CSB), was dried in an oven with air circulation at $40 \pm 2^{\circ} \mathrm{C}$ up to constant weight. After dehydration, it was pulverized in a blender, model $650 \mathrm{~W}$ (Mondial, São Paulo, SP, Brazil), thus obtaining the so-called dry material (DM).

\subsection{Determination of bioactive compounds}

\subsubsection{Extract preparation}

Dried and pulverized CSB was extracted with a $70 \%(\mathrm{w} / \mathrm{v})$ ethanol solution in water according to the percolation process (Brasil, 1959). To obtain the crude extract (CE), the resulting solution was concentrated in a rotary evaporator, model Laborota 4000 (Heidolph, Schwabach, Germany), under low pressure and controlled temperature $\left(40 \pm 5^{\circ} \mathrm{C}\right)$. CE obtained in this way had a dry weight content of $78.85 \pm 0.50 \%$.

\subsubsection{Total polyphenols content}

The solid-phase extraction (SPE) technique was applied to clean $\mathrm{CE}$. For this purpose, $\mathrm{CE}$ was filtered through a C18-SD extraction disk cartridge $(10 \mathrm{~mm} / 6 \mathrm{~mL})$, model $4315 \mathrm{SD}$ (Empore, St. Paul, $\mathrm{MN}$, USA), and the retained fraction first washed with $5.0 \mathrm{mM}$ sulfuric acid then eluted with methanol. All recovered fractions were separately submitted to total polyphenol (TP) quantification according to the Folin Ciocalteu method, as described by Aliakbarian et al. (2011), using a UV-Vis spectrophotometer, model Lambda 25 (Perkin Elmer, Wellesley, MA, USA), at a wavelength of $725 \mathrm{~nm}$, and expressed in milligrams of gallic acid equivalent per 100 gram of dry material $\left(\mathrm{mg}_{\mathrm{GAE}} / 100 \mathrm{~g}_{\mathrm{DM}}\right)$.

\subsubsection{Total flavonoids content}

Total flavonoid (TF) content was determined according to the procedure of Jemai et al. (2009), with adaptations. After diluting $0.25 \mathrm{~mL}$ of CE with $1.25 \mathrm{~mL}$ of distilled water, $75 \mu \mathrm{L}$ of a $5 \% \mathrm{NaNO}_{2}$ solution were added, and the resulting solution was allowed to stand for $5 \mathrm{~min}$. Subsequently, $150 \mu \mathrm{L}$ of a $10 \%$ $\mathrm{AlCl}_{3}$ solution were added, and the sample was allowed to react for $6 \mathrm{~min}$. Finally, $500 \mu \mathrm{L}$ of a $1.0 \mathrm{M} \mathrm{NaOH}$ solution were added, and distilled water was added up to a final volume of $775 \mu \mathrm{L}$.

Samples were read at wavelength of $510 \mathrm{~nm}$, using the same spectrophotometer as above. The blank consisted of all reagents without sample. A calibration curve was constructed with standard methanolic solutions of catechin at concentrations in the range $0.01-0.50 \mathrm{mg} / \mathrm{mL}$, and the results were expressed as milligrams of catechin equivalent per 100 grams of dry material $\left(\mathrm{mg}_{\mathrm{CA}} / 100 \mathrm{~g}_{\mathrm{DM}}\right)$.

\subsubsection{Antioxidant activity - DPPH and ABTS method}

The antioxidant activity of the extract was determined according either to the assay of 2,2-diphenylpicrylhydrazyl radical (DPPH.) inhibition or that of the 2,2'-azino-bis (3-ethylbenzothiazoline) 6-sulfonic acid radical cation $\left(\mathrm{ABTS}^{+}\right)$.

To determine the antioxidant activity according to the DPPH method, $75 \mu \mathrm{L}-\mathrm{CE}$ aliquots were first diluted (1:150) and mixed with $2,925 \mu \mathrm{L}$ of a $25.0 \mathrm{mg} / \mathrm{L} \mathrm{DPPH}$ methanolic solution, which was also used as a blank (Tepe \& Sokmen, 2007). The mixture was then kept at room temperature for $30 \mathrm{~min}$ in the dark, and the absorbance read at $515 \mathrm{~nm}$ using the same UV/Vis spectrophotometer as above. The ability to capture the DPPH radical was expressed as yield of scavenging $\left(Y_{\mathrm{sc}}\right)$, according to the equation 1:

$$
\mathrm{Y}_{\mathrm{Sc}}(\%)=\frac{\mathrm{A}_{\mathrm{b}}-\mathrm{A}_{\mathrm{s}}}{\mathrm{A}_{\mathrm{b}}} \times 100
$$

where $A_{\mathrm{b}}$ is the absorbance of the blank (DPPH) at the start and $A_{\mathrm{s}}$ that of the sample (DPPH plus the extract) after $30 \mathrm{~min}$.

The antioxidant activity was finally expressed as concentration of 6-hydroxy-2,5,7,8-tetramethylchroman-2-carboxylic acid (Trolox) taken as a reference antioxidant, through a calibration curve $(y=0.0774 x-0.0611)$ correlating the percentage inhibition $(y)$ with Trolox concentration $(x)$. The value of IC $_{50}$ was defined as the final concentration, expressed in $\mathrm{mg} / \mathrm{mL}$ of the extract, able to reduce the initial DPPH concentration by $50 \%$.

$\mathrm{CE}$ antioxidant activity was also determined according to the ABTS method (Re et al., 1999), with some modifications. To this purpose, $50 \mu \mathrm{L}-\mathrm{CE}$ aliquots were diluted and added to $1.0 \mathrm{~mL}$ of $\mathrm{ABTS}^{+}$solution, and the absorbance of samples was read after $2 \mathrm{~min}$ of reaction at $734 \mathrm{~nm}$. Antioxidant activity was calculated using a standard Trolox curve expressed in $\mu \mathrm{g} / \mathrm{L}$. The results were finally expressed in $\mathrm{mg}$ of Trolox equivalent antioxidant capacity per $100 \mathrm{~g}$ of crude extract $\left(\mathrm{mg}_{\mathrm{TEAC}} / 100 \mathrm{~g}_{\mathrm{CE}}\right)$.

\subsubsection{Quantification of single polyphenols content}

The contents of the main polyphenols contained in the CE were also quantified by HPLC. For this purpose, standard solutions of gallic acid, protocatechuic acid, epigallocatechin, epicatechin, $p$-coumaric acid and quercetin were prepared at concentration of $0.5 \mathrm{mg} / \mathrm{mL}$, while that of glycosylated quercetin at $0.1 \mathrm{mg} / \mathrm{mL}$. Before the analyses, standard solutions were diluted (1:2) with methanol, while the CE, whose concentration was $100 \mathrm{mg} / \mathrm{mL}$, was filtered through membranes with $0.22 \mu \mathrm{m}$-pore diameter (Millipore, Bedford, MA, USA). Analyses were performed using a HPLC system, model 1100 (Agilent, Palo Alto, CA, USA), coupled with a photodiode array detector (PAD), model 1260 Infinity (Agilent), and equipped with a C18 reverse phase Eclipse plus column $(4.5 \times 250 \mathrm{~mm})$ packed with $5 \mu \mathrm{m}$ diameter particles (Agilent). Samples $(20 \mu \mathrm{L})$ were analyzed at a constant flow rate of $1.0 \mathrm{~mL} / \mathrm{min}$ and a column temperature of $30^{\circ} \mathrm{C}$. The mobile phase was a gradient system, with mobile phase A (methanol/acetonitrile, 1:1) and B (1\% acetic acid in water), varying the mobile phase $\mathrm{B}$, for $0-5 \mathrm{~min}$ to $100 \%, 10 \mathrm{~min}$ to $95 \%$, $30 \mathrm{~min}$ to $70 \%, 40 \mathrm{~min}$ to $60 \%, 45 \mathrm{~min}$ to $52 \%, 55 \mathrm{~min}$ to $30 \%$, 
60-65 min to $0 \%$. Chromatographic peaks of these analytes were detected at $280 \mathrm{~nm}$ for all phenolics. Then they were confirmed by comparing their retention time and DAD-UV spectra with those of reference standards. Quantification was carried out by integration of peaks using the external standard method.

\subsection{Quantification of non-hydrolysable sugars}

For quantification of non-hydrolysable sugars, the extract $(62.5 \mathrm{mg} / \mathrm{mL})$ was filtered before the analyses through membranes with $0.22 \mu \mathrm{m}$-pore diameter (Millipore). Analyses were done by the same HPLC system equipped with a refractive index detector, model HP 1047A (Hewlett Packard, Valley Forge, PA, USA), and a column HI - Plex H (7.7 x $300 \mathrm{~mm})$ (Agilent). Samples $(20 \mu \mathrm{L})$ were analyzed at a constant flow rate of $0.5 \mathrm{~mL} / \mathrm{min}$ and a column temperature of $50{ }^{\circ} \mathrm{C}$. The mobile phase was an isocratic system with $0.01 \mathrm{~N}$ sulfuric acid as the eluent.

\subsection{Physicochemical characterization}

\subsubsection{Nutritional composition and energetic value}

CSB was also analyzed for protein, lipids, carbohydrate, crude fiber, ash and moisture contents according to the Association of Official Analytical Chemists (Horwitz \& Latimer, 2005). The crude protein content was determined by the macro-Kjeldahl method (AOAC 991.02) using N x 6.25 as the nitrogen-to-protein conversion factor, the lipids (AOAC 989.05) by extracting a known mass of powdered sample with petroleum ether in a Soxhlet apparatus, the ash content by incineration at $550 \pm 20^{\circ} \mathrm{C}$ (AOAC 935.42) and the moisture content gravimetrically, while total carbohydrates (including fiber) were calculated by difference. Total energy referred to a mass of $100 \mathrm{~g}$ was calculated according to the equation 2 and the results were presented in $\mathrm{g}$ per $100 \mathrm{~g}$ of dry material (DM).

$$
\operatorname{Energy}(\mathrm{kcal})=4(\mathrm{kcal} / \mathrm{g}) \mathrm{m}_{\mathrm{P}}+4(\mathrm{kcal} / \mathrm{g}) \mathrm{m}_{\mathrm{C}}+9(\mathrm{kcal} / \mathrm{g}) \mathrm{m}_{\mathrm{F}}
$$

where: $m_{\mathrm{P}}, m_{\mathrm{C}}$ and $m_{\mathrm{F}}$ are the masses of proteins, carbohydrates and lipids (g), respectively.

\subsection{Mineral composition}

After digestion of DM and CE samples in 5\% (v/v) $\mathrm{HNO}_{3}$ (Horwitz \& Latimer, 2005), mineral composition was determined in terms of calcium, sodium, potassium, magnesium, manganese, iron, copper, zinc and lead contents, by a fast sequential flame atomic absorption spectrometer, model AA240FS (Varian, Milan, Italy).

\subsection{Total solid content}

The solids content was determined by the gravimetric method using a scale analyzer and infrared heating system, model IV 2000 (Gehaka, São Paulo, Brazil). The results were expressed as weight percent, and all analyses were performed in triplicate.

\subsection{Thermogravimetric behavior}

Thermal Analysis (TGA) and Differential Thermal Analysis (DTA) of CSB and CE were performed by means of a thermal analyzer, model DTG-60 (Shimadzu, Japan), using an aluminum crucible containing approximately $9.0 \mathrm{mg}$ samples, under nitrogen atmosphere $\left(\mathrm{N}_{2}\right)$ and flow rate of $50 \mathrm{~mL} / \mathrm{min}$. Experiments were carried out in the temperature range between 25 and $600{ }^{\circ} \mathrm{C}$, at a heating rate of $10^{\circ} \mathrm{C} / \mathrm{min}$ (Sampaio et al., 2016).

\subsection{Statistical analyses}

Experimental data were subjected to one-way analysis of variance (ANOVA) and Tukey's multiple-range test, using the Statistica version 7.0 software (StatSoft Inc., Tulsa, OK, USA). Differences were considered to be significant at $P<0.05$.

\section{Results and discussion}

\subsection{Bioactive compounds content and antioxidant activity}

Table 1 shows the total polyphenol (TP) content and antioxidant activity of cupuassu seed by-product (CSB) crude extract (CE). TP content of methanolic fraction of dry material extract was more than thrice $\left(16.9 \pm 1.8 \mathrm{mg} / \mathrm{g}_{\mathrm{DM}}\right)$ that reported for cupuassu pulp (5.4 mg/g $\mathrm{g}_{\mathrm{DM}}$ ) (Pugliese et al., 2013), while those of the first two fractions resulting from washing with sulfuric acid (SPE) were negligible. These results are consistent with the observations of Pugliese et al. (2013), who found that seeds and peel had by far higher TP contents than other fruit parts and detected a TP content of seeds 4-5 times higher than that of pulp.

TP content of CE was also significantly higher $(P<0.05)$ than those of some by-products from other tropical fruits such as mango $\left(3.76 \mathrm{mg} / \mathrm{g}_{\mathrm{DM}}\right)$, passion fruit $\left(4.51 \mathrm{mg} / \mathrm{g}_{\mathrm{DM}}\right)$, papaya $\left(7.83 \mathrm{mg} / \mathrm{g}_{\mathrm{DM}}\right)$ and sapotilla $\left(10.53 \mathrm{mg} / \mathrm{g}_{\mathrm{DM}}\right)$ (Ribeiro da Silva et al., 2014), as well as those of grape pomace of different Sicilian cultivars such as Nuello Mascalese $\left(12.36 \mathrm{mg} / \mathrm{g}_{\mathrm{DM}}\right)$, Frappato $\left(6.91 \mathrm{mg} / \mathrm{g}_{\mathrm{DM}}\right)$ and Cabernet Sauvignon $\left(10.65 \mathrm{mg} / \mathrm{g}_{\mathrm{DM}}\right)$

Table 1. Functional properties and pysicochemical characterization of cupuassu seed by-product.

\begin{tabular}{lc}
\hline \multicolumn{1}{c}{ Parameter } & $\begin{array}{c}\text { Cupuassu seed by-product } \\
(\text { dry material })\end{array}$ \\
\hline Moisture content $(\% w / \mathrm{w})$ & $7.6 \pm 0.4$ \\
Non-hydrolyzable sugars $\left(\mathrm{g} / 100 \mathrm{~g}_{\mathrm{DM}}\right)$ & $2.0 \pm 0.2$ \\
Ash content $(\% w / w)$ & $5.2 \pm 0.1$ \\
Solid content $(\% w / w)$ & $49.9 \pm 9.2$ \\
Proteins $(\% w / w)$ & $14.2 \pm 0.2$ \\
Lipids $(\% w / w)$ & $24.4 \pm 0.8$ \\
Carbohydrates $(\% w / w)$ & $26.4 \pm 1.2$ \\
Crude fiber $(\% w / w)$ & $22.2 \pm 0.3$ \\
Energetic value $(\mathrm{kcal} / 100 \mathrm{~g})$ & $382.0 \pm 2.0$ \\
Total phenolic $\left(\mathrm{mg}_{\mathrm{GAE}} \mathrm{g}_{\mathrm{DM}}{ }^{-1}\right)$ & $16.9 \pm 1.8$ \\
Total flavonoids $\left(\mathrm{mg}_{\mathrm{CA}} \cdot \mathrm{g}_{\mathrm{DM}}{ }^{-1}\right)$ & $5.92 \pm 3.4$ \\
$A A_{\mathrm{ABTS}}\left(\mathrm{mg}_{\mathrm{TEAC}} \cdot 100 \mathrm{~g}_{\mathrm{CE}}{ }^{-1}\right)$ & $151.0 \pm 5.5$ \\
$A A_{\mathrm{DPPH}}\left(\mathrm{mM} \mathrm{Trolox} \mathrm{eq.}^{-1}\right)$ & $85.4 \pm 1.7$ \\
$\mathrm{IC}_{50}\left(\mathrm{mg}^{-1} \mathrm{~mL}^{-1}\right)$ & $44.5 \pm 1.5$ \\
\hline
\end{tabular}

Results are expressed as mean of triplicates \pm standard deviation; GAE = gallic acid equivalent; $\mathrm{DM}=$ dry material; $\mathrm{CE}$ = crude extract; $\mathrm{CA}$ = catechin equivalent; $\mathrm{IC}_{50}=$ extract concentration able to reduce the initial DPPH concentration by $50 \%$; $A A_{\mathrm{DPPH}^{*}}=$ antioxidant activity determined according to the DPPH radical assay; $A A_{\mathrm{ABTS}}=$ antioxidant activity determined according to the $\mathrm{ABTS}^{+}$. radical cation assay. 
(Ruberto et al., 2007). It is noteworthy that most of these authors considered as by-products all the non-edible portion of fruits, while in the present study we consider such only the pressed seeds after oil extraction.

The antioxidant activity of CE was determined by both methods of DPPH $\left(A A_{\mathrm{DPPH}^{*}}=85.4 \pm 1.7 \mathrm{mmol} / \mathrm{L}\right)$ and ABTS $^{+}\left(A A_{\mathrm{ABTS}+} \cdot=151.0 \pm 5.7 \mathrm{mg}_{\mathrm{TEAC}} / 100 \mathrm{~g}_{\mathrm{CE}}\right)$ (Table 1$)$. The relatively low $\mathrm{IC}_{50}$ value $(44.5 \pm 1.5 \mathrm{mg} / \mathrm{mL})$ indicates that a small amount of extract was able to inhibit DPPH oxidation by $50 \%$ (Schinella et al., 2010). Fresh cupuassu seeds exhibited lower antioxidant activity than CE either by the DPPH $(32.5-38.3 \mathrm{mmol} / \mathrm{L}$ of fresh weight) (Pugliese et al., 2013). For the $\mathrm{ABTS}^{+}$. method (36.3 mg Trolox/100g of fresh weight), likely due to their lower TP content (Contreras-Calderón et al., 2011). In addition, the above antioxidant activity by the DPPH method of CE was more than twice that of spent coffee grounds (Ballesteros et al., 2014).

Antioxidant compounds have numerous applications in food, cosmetic, and pharmaceutical areas, because they can protect against chronic and degenerative diseases such as cancer and diabetes mellitus, and decrease the risk factors of cardiovascular diseases, among others (Ao et al., 2011). These results suggest the possibility of reusing cupuassu residues to obtain such compounds.

\subsection{Quantification of phenolic compounds in the by-product}

The main phenolics detected in CE by HPLC were gallic, protocatechuic and $p$-coumaric acids, epigallocatechin gallate, epicatechin, glycosylated quercetin and quercetin (Table 2). Other signals with different intensities were observed at different retention times, which can be ascribed to the presence of other flavonoids and/or glycosylated compounds.

Protocatechuic acid was the most abundant phenolic compound of the extract $\left(33.36 \mathrm{mg} / 100 \mathrm{~g}_{\mathrm{DM}}\right)$, followed by glycosylated quercetin $\left(28.01 \mathrm{mg} / 100 \mathrm{~g}_{\mathrm{DM}}\right)$ and epicatechin $\left(20.74 \mathrm{mg} / 100 \mathrm{~g}_{\mathrm{DM}}\right)$. The amounts of quercetin, either glycosylated or not $\left(5.79 \mathrm{mg} / 100 \mathrm{~g}_{\mathrm{DM}}\right)$, are promising taking in mind that these flavonoids exert a protective effect against cardiovascular diseases when assimilated through food in rates 16-24 mg/day (Kris-Etherton et al., 2002). The same applies to epicatechin that was shown to exert a protective effect against isoproterenol-induced oxidative stress thereby reducing cardiac tissue damage (Prince, 2011).

Table 2. Polyphenolic compounds detected at $280 \mathrm{~nm}$ by HPLC in the cupuassu seed by-product and related retention times $(R t)$.

\begin{tabular}{lcc}
\hline \multicolumn{1}{c}{ Compound } & $R t(\mathrm{~min})$ & $\begin{array}{c}\text { Concentration } \\
\left(\mathrm{mg} / 100 \mathrm{~g}_{\mathrm{DM}}\right)\end{array}$ \\
\hline Gallic acid & 8.8 & 5.68 \\
Protocatechuic acid & 17.32 & 33.36 \\
Epigallocatechin gallate & 25.45 & 6.81 \\
Epicatechin & 25.9 & 20.74 \\
p-Coumaric acid & 29.5 & 1.26 \\
Glycosylated quercetin & 35.6 & 28.01 \\
Quercetin & 40.78 & 5.79 \\
\hline
\end{tabular}

$\mathrm{DM}=$ dry material
The above glycosylated quercetin content is consistent with the high levels of glycosylated flavones (mainly quercetin) detected in cupuassu, especially in its unfermented seeds (Pugliese et al., 2013), while that of epicatechin corroborates the findings of Pugliese et al. (2013) and Barros et al. (2016), who identified it in cupuassu seeds either as terminal unit of proanthocyanidin oligomers (4.09 and $29.13 \mathrm{mg} / \mathrm{g}$, respectively) or as extension unit (18.33 and $31.23 \mathrm{mg} / \mathrm{g}$, respectively). On the other hand, unlike these authors, catechin was not detected in our by-product, likely because it was mainly present in the oil fraction.

\subsection{Physicochemical characterization}

Consistently with the high solids content (49.9 $\pm 9.2 \%$ $w / w)$ and estimated carbohydrate content $(26.4 \pm 1.2 \% \mathrm{w} / w)$ of $\mathrm{CE}$, a significant amount of total simple sugars was detected $\left(2.0 \mathrm{~g} / 100 \mathrm{~g}_{\mathrm{DM}}\right)$, being fructose the most abundant of them $\left(1.3 \mathrm{~g} / 100 \mathrm{~g}_{\mathrm{DM}}\right)$, followed by sucrose $\left(0.5 \mathrm{~g} / 100 \mathrm{~g}_{\mathrm{DM}}\right)$ and glucose $\left(0.2 \mathrm{~g} / 100 \mathrm{~g}_{\mathrm{DM}}\right)($ Table 1$)$. These relatively high free sugar contents may have been the result of fruit ripening (Dessimoni-Pinto et al., 2010), during which polysaccharides are partially hydrolyzed to simple sugars.

\subsection{Nutritional composition and energetic value}

Nutritional composition of CSB revealed that carbohydrates $(26.4 \pm 1.2 \% w / w)$ and lipids $(24.4 \pm 0.8 \% w / w)$ were the most abundant macronutrients, followed by fiber $(22.2 \pm 0.3 \% \mathrm{w} / \mathrm{w})$ and proteins $(14.2 \pm 0.2 \% \mathrm{w} / \mathrm{w})$ (Table 1$)$. These contents, which are even better than those reported for the cupuassu pulp (Souza et al., 2011), correspond to an energy value as high as $382.0 \pm 2.0 \mathrm{kcal} / 100 \mathrm{~g}$.

Protein content was $42 \%$ higher than those of fermented or toasted seeds, $56 \%$ higher than that of cocoa seeds (Pugliese et al., 2013), but only half that of roasted and degreased cupuassu seeds (Lopes et al., 2008). Compared to CSB, cocoa seed by-product had higher contents of proteins $(17.30 \pm 0.37 \% w / w)$, sugars $(42.28 \% w / w)$ and lipids $(33.50 \pm 0.53 \% w / w)$, but total fiber content was lower $(15.03 \pm 0.39 \% w / w)$ (Gabbay-Alves et al., 2017). So, the higher fat content of this by-product can be ascribed to oil pressing. CSB moisture content was only $7.6 \pm 0.4 \% w / w$, while that of ash was high $(5.2 \pm 0.1 \% w / w)$ due to the abundance of inorganic compounds.

These results suggest that CSB may be used as an alternative fiber-rich material able to reduce serum levels of triglycerides and glucose (Delcour et al., 2016) and to accelerate the transit of stool through the intestine, thereby contributing to prevent constipation and even colorectal cancer.

\subsection{Mineral elements}

Mineral compositions of dry material (DM) and CE listed Table 3 show statistically significant differences $(P<0.05)$ for almost all the mineral components analyzed. Despite the low Ca content of CE $(7.2 \pm 0.4 \mathrm{mg} / 100 \mathrm{~g})$, the one of DM $(206.6 \pm 19.6 \mathrm{mg} / 100 \mathrm{~g})$ was more than 5 -fold that of cupuassu seeds (36.9 mg/100g) (Naozuka et al., 2011), which suggests the nutritional potential of this by-product. Whereas $\mathrm{Na}$ 
contents of DM and CE were within the limits established by regulatory agencies for healthy diet (Agência Nacional de Vigilância Sanitária, 2005; Institute of Medicine, 2006), those of $\mathrm{Mg}$ and $\mathrm{Zn}$ were close to the limits and almost 3.0 times higher than those of cupuassu seeds (80.2 and 0.73 $\mathrm{mg} / 100 \mathrm{~g}$, respectively) (Naozuka et al., 2011). On the other hand, copper content was higher than those reported for seeds of other Amazonian fruits such as nuts of sapucaia (Lecythis pisonis) (1.15 mg/100g), Brazil nut (Bertholletia excelsa) $(2.18 \mathrm{mg} / 100 \mathrm{~g})$ (Naozuka et al., 2011) and of "umari" variety Y (Poraqueiba sericea Tul.) (3.24 mg/100 g) (Berto et al., $2015)$, even though these values may have been influenced by soil features. Mn content of DM $(4.4 \mathrm{mg} / 100 \mathrm{~g})$ was almost twice the Recommended Daily Intake (RDIs) limits of both Agência Nacional de Vigilância Sanitária (2005) and Institute of Medicine (2006) (Table 3), while that of CE (1.1 mg/100g) complied with both, and an analogous situation occurred for iron, whose content in CE corresponded to $6 \%$ of Fe RDI.
Moreover, $\mathrm{Mg}, \mathrm{Fe}, \mathrm{Zn}$ and $\mathrm{Mn}$ contents of $\mathrm{CE}$ were $32-120 \%$ higher than those of piquiá (Caryocar villosum) seeds and 34-162\% higher than those of biribá ones (Rollinia mucosa) (Berto et al., 2015).

On the other hand, $\mathrm{Pb}$ levels were undetectable in both. Therefore, the most important minerals present in CSB are considered macro and micronutrients essential for the human health.

\subsection{Thermal Behavior}

The TGA and DTA curves (Figure 1) shows the thermal events of the samples between 25 and $600{ }^{\circ} \mathrm{C}$ obtained at a heating rate of $10^{\circ} \mathrm{C} / \mathrm{min}$ under a constant nitrogen atmosphere. DTA is a technique used in conjunction with TGA to obtain information on a sample through the change in temperature. The main function of the TGA-DTA coupling is to provide higher resolution at specific temperatures in which the mass

Table 3. Mineral composition of dry material (DM) and crude extract (CE) of cupuassu seed by-product.

\begin{tabular}{|c|c|c|c|}
\hline Element & $\mathrm{DM}\left(\mathrm{mg} / 100 \mathrm{~g}_{\mathrm{DM}}\right)$ & $\mathrm{CE}\left(\mathrm{mg} / 100 \mathrm{~g}_{\mathrm{DM}}\right)$ & RDI (mg/day) \\
\hline \multicolumn{4}{|c|}{ Macrominerals } \\
\hline $\mathrm{Ca}$ & $206.6 \pm 19.6^{a}$ & $7.2 \pm 0.4^{\mathrm{b}}$ & $1000 / 700^{*}$ \\
\hline $\mathrm{Na}$ & $62.8 \pm 3.9^{\mathrm{a}}$ & $61.9 \pm 8.5^{\mathrm{a}}$ & $1500-2300^{* *}$ \\
\hline $\mathrm{K}$ & $3463 \pm 87^{a}$ & $1648 \pm 75^{\mathrm{b}}$ & $4700^{\star *}$ \\
\hline $\mathrm{Mg}$ & $370.4 \pm 4.4^{\mathrm{a}}$ & $224.7 \pm 9.7^{b}$ & $260 / 100^{*} / 320-420^{* *}$ \\
\hline \multicolumn{4}{|c|}{ Microminerals } \\
\hline $\mathrm{Cu}$ & $3.9 \pm 0.1^{\mathrm{a}}$ & $3.9 \pm 0.1^{\mathrm{a}}$ & $0.900 / 0.440^{\star}-0.900^{\star *}$ \\
\hline $\mathrm{Fe}$ & $16.3 \pm 0.2^{\mathrm{a}}$ & $1.2 \pm 0.1^{\mathrm{b}}$ & $14 / 9.0^{*}-8-18^{* *}$ \\
\hline $\mathrm{Zn}$ & $7.4 \pm 0.2^{\mathrm{a}}$ & $2.2 \pm 0.1^{\mathrm{b}}$ & $7.0 / 5.6^{\star}-8-11^{\star *}$ \\
\hline $\mathrm{Mn}$ & $4.4 \pm 0.1^{\mathrm{a}}$ & $1.1 \pm 0.1^{\mathrm{b}}$ & $2.3 / 1.5^{\star}-1.8-2.3^{\star *}$ \\
\hline $\mathrm{Pb}$ & ND & ND & - \\
\hline
\end{tabular}

$\mathrm{DM}=$ dry material; $\mathrm{CE}=$ crude extract; $\mathrm{RDI}=$ Recommended Daily Intake for adults/children up to 10 years according to *Agência Nacional de Vigilância Sanitária (2005) or ${ }^{\star *}$ Institute of Medicine (2006). ND = not detectable. Experimental values obtained in this work are expressed as means of triplicates ( $\mathrm{n}=3$ ) \pm standard deviation. Mean values in the same line with the same letters do not differ significantly at $5 \%$ confidence level according to the Tukey's test.

A

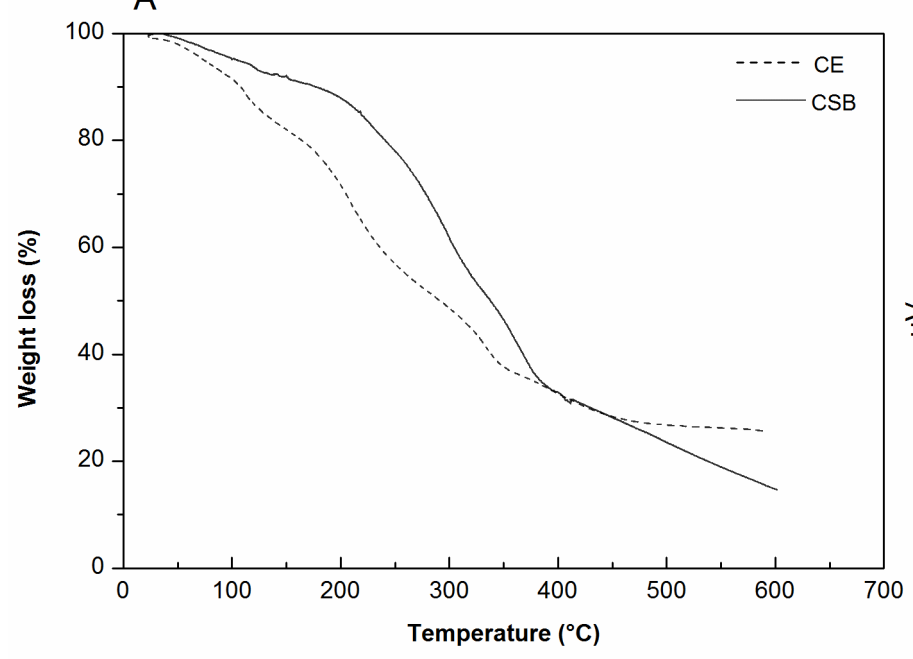

B

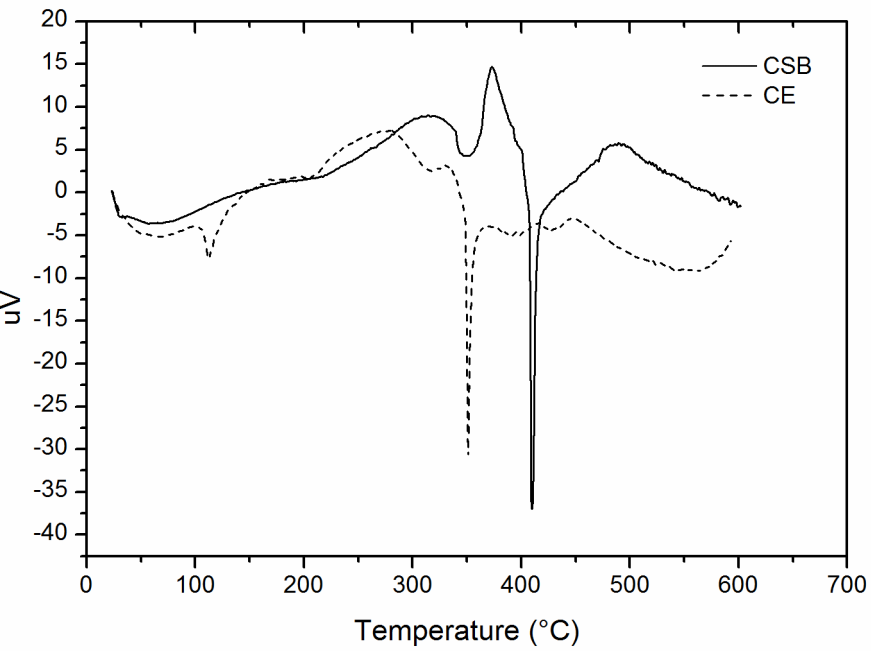

Figure 1. TGA (A) and DTA (B) curves obtained for cupuassu seeds by-product (CSB) and their crude extract (CE), at $10{ }^{\circ} \mathrm{C} / \mathrm{min}$, under $\mathrm{N}_{2}$ atmosphere and flow rate of $50 \mathrm{~mL} / \mathrm{min}$. 
variation is small and successive to other mass losses, leaving the visualization only by the graph of mass vs. temperature (typical of TGA) (Ionashito et al., 2004).

The thermograms obtained for CSB and CE exhibited three and two steps of mass decomposition, respectively. The first event evidenced by TGA curves (Figure $1 \mathrm{~A}$ ) at $150^{\circ} \mathrm{C}$ corresponds to weight losses of about $8.6 \%$ and $12.9 \%$, respectively, as a result of the water evaporation (dehydration of the samples), while the DTA curves (Figure 1B) highlighted a small endothermic event in a close temperature range $\left(115.86-128.66{ }^{\circ} \mathrm{C}\right)$. The greatest transformation and mass losses occurred during the second thermal step, evidenced by the TGA curve in the temperature range $200-400{ }^{\circ} \mathrm{C}$, may be related to the onset of thermal decomposition of carbohydrates, fibers, proteins and $8-25 \%$ of vegetable oil residue due to pyrolysis of cupuassu fat. It implied the largest mass loss ( $57.4 \%$ and $60.6 \%$, respectively) and resulted in a large endothermic peak $\left(407.88-413.58{ }^{\circ} \mathrm{C}\right.$ and $339.24-365.23^{\circ} \mathrm{C}$, respectively). CSB also presented a third thermal event of mass loss $(18.8 \%)$, from 400 to $600{ }^{\circ} \mathrm{C}$, related to thermal degradation of these compounds present in the complex by-product mixture.

\section{Conclusion}

Full utilization of the agroindustrial by-product of cupuassu seeds, which is routinely wasted, has never been obtained until today, even though there is evidence to support its potential. The results of this study did in fact demonstrate that this by-product still possesses significant amounts of bioactive compounds with antioxidant activity and nutritional potential, which opens up possibilities for its reutilization in different biotechnological processes. It showed significant concentrations of macronutrients such as fibers, crude fat and carbohydrates as ingredients that may be exploited industrially. In addition, CSB extract exhibited interesting contents of minerals, phenolic compounds and flavonoids. These results suggest that cupuassu by-product may be used as preservative in food formulations, as natural antioxidant source in food and pharmaceutical products, or as raw material to obtain new functional ingredients for food industry, thus acquiring economic value and reducing the production of fruit processing waste. CSB is also physical thermal resistance in a large range of temperature, hence being suitable for the manufacture and encapsulation of biomaterials for several industrial purposes. Despite some efforts have recently been made to find possible alternatives to reuse this residue, the implementation of industrial processes using it as raw material is still a challenge to be faced. This study gives support to address further research and developments in this area.

\section{Acknowledgements}

À Coordenação de Aperfeiçoamento de Pessoal de Nível Superior (CAPES) pela concessão da bolsa de Doutorado para Russany Silva da Costa.

\section{References}

Agência Nacional de Vigilância Sanitária - ANVISA. (2005). Regulamento técnico sobre a ingestão diária recomendada de proteínas, vitaminas e minerais (Resolução RDC no 269, de 22 de setembro de 2005). Diário Oficial [da] República Federativa do Brasil.

Aliakbarian, B., Casazza, A. A., \& Perego, P. (2011). Valorization of olive oil solid waste using high pressure-high temperature reactor. Food Chemistry, 128(3), 704-710. http://dx.doi.org/10.1016/j. foodchem.2011.03.092.

Ao, C., Higa, T., Khanh, T. D., Upadhyay, A., \& Tawata, S. (2011). Antioxidant phenolic compounds from Smilax sebeana Miq. Lebensmittel-Wissenschaft + Technologie, 44(7), 1681-1686. http:// dx.doi.org/10.1016/j.lwt.2011.02.001.

Ayala-Zavala, J. F., Vega-Vega, V., Rosas-Domínguez, C., Palafox-Carlos, H., Villa-Rodriguez, J. A., Siddiqui, M. W., Dávila-Aviña, J. E., \& González-Aguilar, G. A. (2011). Agro-industrial potential of exotic fruit byproducts as a source of food additives. Food Research International, 44(7), 1866-1874. http://dx.doi.org/10.1016/j.foodres.2011.02.021.

Ballesteros, L. F., Teixeira, J. A., \& Mussatto, S. I. (2014). Chemical, Functional, and Structural Properties of Spent Coffee Grounds and Coffee Silverskin. Food and Bioprocess Technology, 7(12), 3493-3503. http://dx.doi.org/10.1007/s11947-014-1349-z.

Barros, H. R. M., García-Villalba, R., Tomás-Barberán, F. A., \& Genovese, M. I. (2016). Evaluation of the distribution and metabolism of polyphenols derived from cupuassu (Theobroma grandiflorum) in mice gastrointestinal tract by UPLC-ESI-QTOF. Journal of Functional Foods, 22, 477-489. http://dx.doi.org/10.1016/j.jff.2016.02.009.

Berto, A., Silva, A. F., Visentainer, J. V., Matsushita, M., \& Souza, N. E. (2015). Proximate compositions, mineral contents and fatty acid compositions of native Amazonian fruits. Food Research International, 77(3), 441-449. http://dx.doi.org/10.1016/j.foodres.2015.08.018.

Brasil. Agência Nacional de Vigilância Sanitária. (1959). Farmacopeia Brasileira (2. ed.). São Paulo: Gráfica Siqueira.

Carvalho, J. E. U., Müller, H. C., Alves, M. R., \& Nazaré, R. F. R. (2004). Cupuacuzeiro (Comunicado técnico, 115). Brazil. Embrapa Amazônia Oriental. Retrieved from http://ainfo.cnptia.embrapa.br/digital/ bitstream/item/18786/1/com.tec.115.pdf

Contreras-Calderón, J., Calderón-Jaimes, L., Guerra-Hernández, E., \& García-Villanova, B. (2011). Antioxidant capacity, phenolic content and vitamin $\mathrm{C}$ in pulp, peel and seed from 24 exotic fruits from Colombia. Food Research International, 44(7), 2047-2053. http:// dx.doi.org/10.1016/j.foodres.2010.11.003.

Delcour, J. A., Aman, P., Courtin, C. M., Hamaker, B. R., \& Verbeke, K. (2016). Prebiotics, fermentable dietary fiber, and health claims. Advances in Nutrition, 7(1), 1-4. http://dx.doi.org/10.3945/ an.115.010546. PMid:26773010.

Dessimoni-Pinto, N. V., Silva, V. M., Batista, A. G., Vieira, G., Souza, C. R., Dumont, P. V., \& Santos, G. K. M. (2010). Características físico-químicas da amêndoa de macaúba e seu aproveitamento na elaboração de barras de cereais. Food and Nutrition, 21(1), 79-86.

Gabbay Alves, T. V., Costa, R. S., Aliakbarian, B., Casazza, A. A., Perego, P., Arruda, M. S. P., Silva, J. O. C. Jr, \& Converti, A. (2017). Bioactive compounds and antioxidant potential for polyphenol-rich cocoa extract obtained by agroindustrial residue. Natural Product Research, 1-4. http://dx.doi.org/10.1080/14786419.2017.1399381 . PMid:29126366.

Horwitz, W. \& Latimer, G. W. (2005). Official methods of analysis of AOAC International (18th ed.). Gaithersburg: AOAC International.

Ignat, I., Volf, I., \& Popa, V. I. (2011). A critical review of methods for characterization of polyphenolic compounds in fruits and vegetables. 
Food Chemistry, 126(4), 1821-1835. http://dx.doi.org/10.1016/j. foodchem.2010.12.026. PMid:25213963.

Institute of Medicine. (2006). Dietary reference intakes: The essential guide to nutrient requirements. Washington: National Academy of Sciences.

Ionashiro, M., Caires, F. j., \& Gomes, D. J. C. (2004). Giolitto: Fundamentos da Termogravimetria, Análise Térmica Diferencial e Calorimetria Exploratória Diferencial. São Paulo: Giz Editorial.

Janissen, B., \& Huynh, T. (2018). Chemical composition and valueadding applications of coffee industry byproducts: A review. Resources, Conservation and Recycling, 128, 110-117. http://dx.doi. org/10.1016/j.resconrec.2017.10.001.

Jemai, H., Bouaziz, M., \& Sayadi, S. (2009). Phenolic composition, sugar contents and antioxidant activity of Tunisian sweet olive cultivar with regard to fruit ripening. Journal of Agricultural and Food Chemistry, 57(7), 2961-2968. http://dx.doi.org/10.1021/jf8034176. PMid:19334763.

Kris-Etherton, P. M., Hecker, K. D., Bonanome, A., Coval, S. M., Binkoski, A. E., Hilpert, K. F., Griel, A. E., \& Etherton, T. D. (2002). Bioactive compounds in foods: their role in the prevention of cardiovascular disease and cancer. The American Journal of Medicine, 113(9, Suppl. 9B), 71S-88S. http://dx.doi.org/10.1016/S0002-9343(01)00995-0. PMid:12566142.

Lopes, A. S., Pezoa-García, N. H., \& Amaya-Farfán, J. (2008). Qualidade nutricional das proteínas de cupuaçu e de cacau. Food Science and Technology, 28(2), 263-268. http://dx.doi.org/10.1590/S010120612008000200001.

Naozuka, J., Carvalho-Vieira, E., Nascimento, N. A., \& Oliveira, P. V. (2011). Elemental analysis of nuts and seeds by axially viewed ICP OES. Food Chemistry, 124(4), 1667-1672. http://dx.doi.org/10.1016/j. foodchem.2010.07.051.

Pantaleón-Velasco, M. R., Ruiz-López, I. I., Pérez-Silva, A., BravoClemente, L., Mateos, R., Ruiz-Espinosa, H., \& Angeles, V. M. (2014). Antioxidant and functional properties of a high dietary fibre powder from carambola (Averrhoa carambola L.) pomace. International Journal of Food Science \& Technology, 49(9), 21012110. http://dx.doi.org/10.1111/ijfs.12519.

Prince, P. S. M. (2011). A biochemical, electrocardiographic, electrophoretic, histopathological and in vitro study on the protective effects of (-) epicatechin in isoproterenol-induced myocardial infarcted rats. European Journal of Pharmacology, 671(1-3), 95-101. http://dx.doi. org/10.1016/j.ejphar.2011.09.036. PMid:21958876.
Pugliese, A. G., Tomas-Barberan, F. A., Truchado, P., \& Genovese, M. I. (2013). Flavonoids, proanthocyanidins, vitamin C, and antioxidant activity of Theobroma grandiflorum (Cupuassu) pulp and seeds. Journal of Agricultural and Food Chemistry, 61(11), 2720-2728. http://dx.doi.org/10.1021/jf304349u. PMid:23431956.

Re, R., Pellegrini, N., Proteggente, A., Pannala, A., Yang, M., \& RiceEvans, C. (1999). Antioxidant activity applying an improved ABTS radical cation decolorization assay. Free Radical Biology \& Medicine, 26(9-10), 1231-1237. http://dx.doi.org/10.1016/S0891-5849(98)003153. PMid:10381194.

Ribeiro da Silva, L. M., Teixeira de Figueiredo, E. A., Silva Ricardo, N. M., Pinto Vieira, I. G., Wilane de Figueiredo, R., Brasil, I. M., \& Gomes, C. L. (2014). Quantification of bioactive compounds in pulps and by-products of tropical fruits from Brazil. Food Chemistry, 143, 398-404. http://dx.doi.org/10.1016/j.foodchem.2013.08.001. PMid:24054258.

Ruberto, G., Renda, A., Daquino, C., Amico, V., Spatafora, C., Tringali, C., \& Tommasi, N. (2007). Polyphenol constituents and antioxidant activity of grape pomace extracts from five Sicilian red grape cultivars. Food Chemistry, 100(1), 203-210. http://dx.doi.org/10.1016/j. foodchem.2005.09.041.

Sampaio, R. C. A., Costa, R. S., Souza, C. R. F., Duarte, A. P. Jr, RibeiroCosta, R. M., Costa, C. E. F., Oliveira, W. P., Converti, A., \& Silva, J. O. C. Jr (2016). Thermal characterization of Arrabidaea chica (Humb. \& Bonpl.) B. Verl. dry extracts obtained by spray dryer. Journal of Thermal Analysis and Calorimetry, 123(3), 2469-2475. http://dx.doi.org/10.1007/s10973-015-5123-x.

Schinella, G., Mosca, S., Cienfuegos-Jovellanos, E., Pasamar, M. A., Muguerza, B., Ramón, D., \& Ríos, J. L. (2010). Antioxidant properties of polyphenol-rich cocoa products industrially processed. Food Research International, 43(6), 1614-1623. http://dx.doi.org/10.1016/j. foodres.2010.04.032.

Souza, M. S. B., Vieira, L. M., Silva, M. J. M., \& Lima, A. (2011). Nutritional characterization of antioxidant compounds in tropical fruit pulp residues. Ciência e Agrotecnologia, 35(3), 544-559. http:// dx.doi.org/10.1590/S1413-70542011000300017.

Tepe, B., \& Sokmen, A. (2007). Screening of the antioxidative properties and total phenolic contents of three endemic Tanacetum subspecies from Turkish flora. Bioresource Technology, 98(16), 3076-3079. http://dx.doi.org/10.1016/j.biortech.2006.10.019. PMid:17157500. 